\title{
A Cellular Model for Studying Accommodation to Environmental Stressors: Protection and Potentiation by Cadmium and Other Metals
}

\author{
B. Chin, G. S. Lesowitz, and I. A. Bernstein \\ Department of Environmental and Industrial Health. School of Public Health, \\ The University of Michigan, Amn Arbor, Michigan 48109
}

Received June 13, 1977

\begin{abstract}
Exposure of $P$. polycephalum to a subthreshold challenge of $\mathrm{Cd}^{2+}$, which did not delay mitosis. elicited a protective response against a mitotic delay resulling from subsequent exposure to a suprathreshold challenge of $\mathrm{Cd}^{2+}$. Some characteristics of this protective response are herein identified. The concentration of $\mathrm{Cd}^{2+}$ in the subthreshold challenge could be lowered to $10^{-5} \mathrm{M}$ and maintain complete protection against a suprathreshold challenge of $5 \times 10^{-4} \mathrm{M} \mathrm{Cd}^{2+}$. A subthreshold challenge of $10^{-4} \mathrm{M}$ provided full protection against a $\mathrm{Cd}^{2+}$ concentration of $7 \times 10^{-4} \mathrm{M}$. A subthreshold challenge of $10^{-4} \mathrm{M} \mathrm{Cd}^{2+}$ could be placed anywhere in the cell cycle approaching but not abutting a suprathreshold challenge of $5 \times 10^{-4} \mathrm{M} \mathrm{Cd}^{2+}$ in late $\mathrm{G}_{2}$ and still provide complete protection with the exception of one point in early S. At that point, $10^{-4} \mathrm{M} \mathrm{Cd}^{2+}$ by itself was toxic to the cell: partial protection, however, developed. Other responses developed when metals were substituted for cadmium. $\mathrm{Cd}^{2+}$ protected against exposure to $\mathrm{Hg}^{2+}$ and $\mathrm{Ni}^{2+}$ but potentiated exposures to $\mathrm{Co}^{2+}$, $\mathrm{Cu}^{2+}, \mathrm{Pb}^{2+}$, or $\mathrm{Zn}^{2+}$. A curious observation is that exposure to $\mathrm{Hg}^{2+}$ and $\mathrm{Ni}^{2+}$ protected against exposure to $\mathrm{Cd}^{2+}$, while exposure to $\mathrm{Co}^{2+}, \mathrm{Pb}^{2+}$, or $\mathrm{Zn}^{2+}$ potentiated exposure to $\mathrm{Cd}^{2+}$. $\mathrm{Hg}^{2+}$ and $\mathrm{Ni}^{2+}$ protected against reexposure to themselves.
\end{abstract}

\section{INTRODUCTION}

In an accompanying report (Chin et al., 1978), a model was formulated to evaluate the effect of a subtoxic stressor upon the integrity of a cell, to determine if there is a threshold for stress. The model proposed that subthreshold challenge might alter the response of the cell to subsequent suprathreshold challenge. In testing the model, exposures to $\mathrm{Cd}^{2+}$ during the cell cycle were used as stressors, and delays in subsequent mitoses were taken as effects of the stressors upon the integrity of the cell. The validity of our model was substantiated: Exposure to $10^{-4}$ $\mathrm{M} \mathrm{Cd}^{2+}$ for $30 \mathrm{~min}$ in early $\mathrm{G}_{2}(0.45$ cycle $)$, a subthreshold challenge which did not delay mitosis, protected Physarum polycephalum against a mitotic delay of 105 min resulting from a suprathreshold challenge of $4 \times 10^{-4} \mathrm{M} \mathrm{Cd}^{2+}$ for $30 \mathrm{~min}$ in late $\mathrm{G}_{2}(\mathbf{0 . 7 5}$ cycle $)$.

This protective response is of interest because cadmium has only recently become an environmental pollutant of concern (Flick et al., 1971; Vallee and Ulmer, 1972 ) as a consequence of industrial processing developed in the twentieth century (Page and Bingham, 1973). The extraction of this minor constituent from the earth's crust, its concentration during fabrication, and its dissemination into the biosphere as finished products (electroplated materials, pigments, chemicals, alloys, plastics) and as waste products-in short, the processing of cadmiumresults in low-level exposures whose biological hazard has yet to be evaluated. Chronic exposures of populations to cadmium in industrial runoff have resulted in 
disorders of epidemiologic proportions, as in Itai-itai outbreaks in Japan (Emmerson, 1970). As early as 1938, Bulmer et al. reported that exposure of individuals to very high levels lead rapidly to death. Daily exposure to the low levels of cadmium found in an industrialized society may be more insidious, especially since cadmium has been implicated in hypertension (Schroeder, 1965), teratogenesis (Ferm and Carpenter, 1967: Ferm, 1972; Scharpf et al., 1972), and carcinogenesis (Gunn et al., 1963; Haddow et al., 1964; Malcolm, 1972; Lucis et al., 1972). Although cell necrosis is a consequence of exposure to cadmium (Parizek and Zahor, 1956), the biochemical bases of cadmium toxicity remain to be identified.

This paper reports some characteristics of a protective response to $\mathrm{Cd}^{2+}$ : the amount of protection provided by a subthreshold exposure, the availability of the protective response through the cell cycle, the time required for protection to develop, and the consequences of substituting other metals for cadmium in the model.

As we predicted in our model (Chin et al., 1978), potentiation as well as protection are possible cellular responses to subtoxic environmental stress. Both are demonstrated in this paper.

\section{METHODS}

These procedures are summarized from the accompanying report of Chin et al. (1978).

Physarum polycephalum, strain $\mathrm{M}_{3} \mathrm{CV}$, was maintained in submerged culture at $23^{\circ} \mathrm{C}$. Plasmodia were established by fusing washed and starved microplasmodia for $4 \mathrm{hr}$. Mitoses were naturally synchronized after addition of growth medium. These studies were conducted between the first (MI) and second (MII) mitoses, which had a periodicity of 12 to $14 \mathrm{hr}$. Early prophase served as the end point to identify $M$. The length of the cell cycle, the timing of exposure, and the effect of exposure were determined by measuring the interval between MI and MII.

Up to 16 replicate disks were excised from the growing edge of a $7-\mathrm{cm}$ plasmodium with a $12-\mathrm{mm}$ cork borer without loss of synchrony among disks (Chin $e t$ al., 1972).

The organism was challenged by floating replicate disks in $20 \mathrm{ml}$ of medium containing an appropriate concentration of metal ion. The challenge was terminated by lifting the disks from the exposure medium and washing them twice upon fresh medium. Incubation was continued on fresh medium. Replicate disks could be challenged repetitively within one cycle with appropriate controls for each combination of exposures. The response to a stressor(s) was measured as a delay in the timing of mitosis compared to the timing in control replicates which were not challenged. Two replicate disks were tested in each exposure and duplicate disks usually reached MII within minutes of each other. A difference of 20 min between average MII times for control and exposed disks was considered significant: The timing of MII from the fastest (Time 0 ) to the slowest replicate disk for $\mathbf{n}$ $=8$ replicate disks prepared $8 \mathrm{hr}$ before MII fell within a range of $14 \mathrm{~min}$, with $\overline{\mathrm{x}}=$ $5.13 \pm 4.94 \mathrm{~min}$ from and including Time 0 ; calculations for replicate disks prepared from other plasmodia were on the same order of magnitude (Chin et al.. 1972).

The suitability of this model for studying cellular responses to single and multi- 
ple stress lies in the ability to mark precisely exposure points within the cell cycle and to measure the effect of each exposure, singly and in combination, on progress throughout the cycle.

\section{RESULTS}

The discovery of a protective response to cadmium in Physarum (Chin et al., 1978) prompted us to inquire how low the subthreshold challenge could be depressed without loss of protection. In the absence of any information on this phenomenon, the approach was to start with a completely protected system and then to modify each parameter of that system one at a time. A subthreshold exposure of $30 \mathrm{~min}$ to $10^{-4} \mathrm{M} \mathrm{Cd}^{2+}$ at 0.45 cycle provided complete protection against a 30-min exposure to $5 \times 10^{-4} \mathrm{M} \mathrm{Cd}^{2+}$ at 0.75 cycle, which when given alone delayed mitosis by $118 \mathrm{~min}$. The subthreshold concentration could be reduced to $10^{-5} \mathrm{M}$ and still maintain full protection against the $5 \times 10^{-4} \mathrm{M}$ exposure, a 50-fold increase in $\mathrm{Cd}^{2+}$ concentration (Table 1), but the protective response fell off when the subthreshold dose was further reduced to $5 \times 10^{-6} \mathrm{M} \mathrm{Cd}^{2+}$. When the suprathreshold challenge was increased, the upper limit for full protection provided by $10^{-5} \mathrm{M} \mathrm{Cd}^{2+}$ was found to be $5 \times 10^{-4} \mathrm{M} \mathrm{Cd}^{2+}$ (Expt 1, Table 2). As the suprathreshold dose was raised from $6 \times 10^{-4}$ to $10 \times 10^{-4} \mathrm{M}$, protection again fell off. Raising the subthreshold challenge to $10^{-4} \mathrm{M}$ only increased the limit of full protection slightly, by less than one order of magnitude (Expt 2, Table 2).

The availability of the protective response throughout the cell cycle was tested by maintaining the suprathreshold challenge in late $\mathrm{G}_{2}$ (following MI) and applying the subthreshold challenge at regular intervals, starting at MI and encroaching upon the suprathreshold challenge. Protection was available throughout the greater part of the cell cycle (Table 3). Loss of full protection, however, occurred when the subthreshold challenge was applied in early $S(0.16$ cycle) (Expt 1 , Table 3 ). In this instance, the supposed subthreshold challenge actually caused a mitotic delay of $130 \mathrm{~min}$, which is probably a reflection of the increased sensitivity to cadmium during this period in the cell cycle (Chin et al., 1978). Loss of full

TABLE 1

The Effect of Decreasing Subthreshold Challenges on the Protective Response"

\begin{tabular}{|c|c|c|}
\hline \multicolumn{2}{|c|}{ Exposure to $\mathrm{Cd}^{2+}$} & \multirow{2}{*}{$\begin{array}{l}\text { Average MII delay } \\
\text { (min) }\end{array}$} \\
\hline At 0.45 cycle & At 0.75 cycle & \\
\hline- & - & - \\
\hline- & $5 \times 10^{-+} \mathrm{M}$ & 118 \\
\hline $10^{-1} \mathrm{M}$ & $5 \times 10^{-4} \mathrm{M}$ & 5 \\
\hline $5 \times 10^{-5} \mathrm{M}$ & $5 \times 10^{-4} \mathrm{M}$ & -5 \\
\hline $10^{-5} \mathrm{M}$ & $5 \times 10^{-4} \mathrm{M}$ & 14 \\
\hline $5 \times 10^{-6} \mathrm{M}$ & $5 \times 10^{-4} \mathrm{M}$ & 88 \\
\hline
\end{tabular}

" Replicate disks from one plasmodium were exposed to a subthreshold dose of cadmium for 30 min at 0.45 cycle and to a suprathreshold dose for $30 \mathrm{~min}$ at 0.75 cycle. Unexposed disks and disks exposed to only one of the two challenges were maintained as controls. All samples were done in duplicate; the timing of mitosis between duplicate disks was $20 \mathrm{~min}$ or less. The experiment was evaluated by measuring the effect of single and multiple exposures upon the timing of the following mitosis, MII. 
TABLE 2

The Upper Limit of Full Protection Provided by Subthreshol.d Challenges

\begin{tabular}{|c|c|c|c|}
\hline \multirow[b]{2}{*}{ Experiment No. } & \multicolumn{2}{|c|}{ Exposure to $\mathrm{Cd}^{2+}$} & \multirow{2}{*}{$\begin{array}{l}\text { Average MII delay } \\
\qquad(\mathrm{min})\end{array}$} \\
\hline & At 0.45 cycle & At 0.75 cycle & \\
\hline \multirow[t]{7}{*}{1} & - & - & - \\
\hline & - & $6 \times 10^{-4} \mathrm{M}$ & 162 \\
\hline & - & $8 \times 10^{-4} \mathrm{M}$ & 169 \\
\hline & - & $10^{-3} \mathrm{M}$ & 195 \\
\hline & $10^{-5} \mathrm{M}$ & $6 \times 10^{-1} \mathrm{M}$ & 41 \\
\hline & $10^{-\bar{n}} \mathrm{M}$ & $8 \times 10^{-t} M$ & 94 \\
\hline & $10^{-.5} \mathrm{M}$ & $10^{-3.3} \mathrm{M}$ & 121 \\
\hline \multirow[t]{7}{*}{2} & - & - & - \\
\hline & - & $6 \times 10^{-4} M$ & 131 \\
\hline & - & $8 \times 10^{-4} M$ & 163 \\
\hline & 一 & $10^{-3} \mathrm{M}$ & 169 \\
\hline & $10^{-4} \mathrm{M}$ & $6 \times 10^{-4} \mathrm{M}$ & 7 \\
\hline & $10^{-4} \mathrm{M}$ & $8 \times 10^{-4} \mathrm{M}$ & 23 \\
\hline & $10^{-4} \mathrm{M}$ & $10^{3} \mathrm{M}$ & 47 \\
\hline
\end{tabular}

"Replicate disks from one plasmodium were exposed to a subthreshold dose of cadmium ion for 30 min at 0.45 cycle and to a suprathreshold doses for $30 \mathrm{~min}$ at $0.75 \mathrm{cycle}$. Unexposed disks and disks exposed to only one of the two challenges were maintained as controls. All samples were done in duplicate; the timing of mitosis between duplicate disks was $20 \mathrm{~min}$ or less. The experiments were evaluated by measuring the effect of single and multiple exposures upon the timing of the following mitosis. MII.

protection was not as surprising as finding the cell "rescued" from the toxic effects of both exposures: The combination of exposures at 0.16 and 0.82 cycle provided partial protection with a resultant mitotic delay $(80 \mathrm{~min})$ that was less than the mitotic delay from either exposure alone ( 130 and $158 \mathrm{~min}$, respectively). This rescue phenomenon was complete when exposures were combined at 0.06 and 0.82 cycle (Expt 1, Table 3); full protection developed against individual mitotic delays of 122 and $158 \mathrm{~min}$, respectively.

When the subthreshold challenge was maintained at 0.45 cycle but the suprathreshold challenge was advanced, full protection was lost (Table 4). Apparently some finite period of time, $\sim 30 \mathrm{~min}$, must intervene between challenges for complete protection to develop.

Specificity for cadmium in the protective response was tested next. Rather than to develop sensitivity profiles and dose-response curves for other divalent metal cations of current interest $(\mathrm{Co}, \mathrm{Cu}, \mathrm{Fe}, \mathrm{Hg}, \mathrm{Mn}, \mathrm{Pb}$, and $\mathrm{Zn}$ ), we tested each metal directly in the biological assay under the conditions developed for cadmium. Exposures to $5 \times 10^{-4} \mathrm{M}$ concentration of other metal ions except $\mathrm{Hg}^{2+}$ at 0.75 cycle were below the threshold for mitotic delay (Table 5). Adjustments in ion concentration were necessary to induce suitable delays with a single challenge. and some, approaching $10^{-2} \mathrm{M}$, were still not effective. At 0.45 cycle a subthreshold $\mathrm{Cd}^{2+}$ challenge was tested for its ability to protect the organism against other metal ions at concentrations up to $10^{-2} \mathrm{M}$ at 0.75 cycle (Table 5). Cadmium protected against two other metals, $\mathrm{Hg}^{2+}$ and $\mathrm{Ni}^{2+}$. Furthermore, as we predicted 
TABLE 3

The Availabiluty of the Protective Response in the Cell Cycle ${ }^{\prime}$

\begin{tabular}{|c|c|c|c|}
\hline \multirow[b]{2}{*}{ Experiment No. } & \multicolumn{2}{|c|}{ Exposure to $\mathrm{Cd}^{2+}$} & \multirow{2}{*}{$\begin{array}{c}\text { Average MII delay } \\
\text { (min) }\end{array}$} \\
\hline & $10^{-4} \mathrm{M}$ & $5 \times 10^{-1} \mathrm{M}$ & \\
\hline \multirow[t]{8}{*}{1} & - & - & - \\
\hline & 0.06 cycle & - & 122 \\
\hline & 0.16 cycle & - & 130 \\
\hline & 0.27 cycle & - & 0 \\
\hline & - & 0.82 cycle & 158 \\
\hline & 0.06 cycle & 0.82 cycle & 11 \\
\hline & 0.16 cycle & 0.82 cycle & 80 \\
\hline & 0.27 cycle & 0.82 cycle & 16 \\
\hline \multirow[t]{8}{*}{2} & - & - & - \\
\hline & 0.36 cycle & - & 10 \\
\hline & 0.46 cycle & - & 11 \\
\hline & 0.56 cycle & - & 0 \\
\hline & - & 0.78 cycle & 98 \\
\hline & 0.36 cycle & 0.78 cycle & 17 \\
\hline & 0.46 cycle & 0.78 cycle & 0 \\
\hline & 0.56 cycle & 0.78 cycle & 12 \\
\hline \multirow[t]{4}{*}{3} & - & - & - \\
\hline & 0.65 cycle & - & 47 \\
\hline & - & 0.72 cycle & 131 \\
\hline & 0.65 cycle & 0.72 cycle & 51 \\
\hline
\end{tabular}

${ }^{a}$ Replicate disks were exposed to selected concentrations of cadmium ion for 30 min at regular intervals through the cell cycle. For convenience, this analysis was performed in three parts (Expts 1-3). Unexposed disks and disks exposed to only one of the two challenges were maintained as controls. All samples were done in duplicate: the timing of mitosis between duplicate disks was 20 min or less. The experiments were evaluated by measuring the effect of single and multiple exposures upon the timing of the following mitosis, MII.

in our model for accommodation (Chin et al., 1978), other responses to the subthreshold challenge were observed. Accommodations to mixed challenges (Table 5) were separated into three groups: (1) potentiation, in which the double challenge response was a delay greater than the sum of the single challenge delays, e.g., $\mathrm{Co}^{2+}, \mathrm{Cu}^{2+}, \mathrm{Pb}^{2+}$, and $\mathrm{Zn}^{2+}$; (2) protection, in which the double challenge response was a delay less than the sum of single challenge delays, e.g., $\mathrm{Cd}^{2+}$, $\mathrm{Hg}^{2+}$, and $\mathrm{Ni}^{2+}$; and (3) no response, in which the double challenge response was a delay equal to the sum of the single challenge delays, e.g., with $\mathrm{Fe}^{2+}$ and $\mathrm{Mn}^{2+}$. More work is needed to determine whether changes in $\mathrm{Fe}^{2+}$ and $\mathrm{Mn}^{2+}$ levels and in other ions as well will result in redistributions within these three groups.

When the sequence of mixed exposures was reversed (Table 6), i.e., low levels of selected metal ions $\left(10^{-5} \mathrm{M}\right)$ at 0.45 cycle preceded suprathreshold doses $(5 \times$ $10^{-4} \mathrm{M}$ ) of cadmium at 0.75 cycle, almost identical groupings of divalent cations were found: (1) $\mathrm{Co}^{2+}, \mathrm{Cu}^{2+}, \mathrm{Pb}^{2+}$, and $\mathrm{Zn}^{2+}$ again comprised the potentiating group; (2) $\mathrm{Cd}^{2+}$ and $\mathrm{Hg}^{2+}$ were the protecting group; and (3) $\mathrm{Fe}^{2+}$ and $\mathrm{Mn}^{2+}$ were the group without response. At $10^{-5} \mathrm{M}, \mathrm{Ni}^{2+}$ was in the last group. Since cadmium provided some protection against nickel (Table 5), an experiment was undertaken 
TABLE 4

Time Course for Development of the protecitve Response: Thf. Effect of Advancing the. Suprathreshold (Late) Challfinge. Toward the Subthreshold (Early Challenge)

\begin{tabular}{ccc}
\hline \multicolumn{2}{c}{ Exposure to $\mathrm{Cd}^{2+}$} & \multicolumn{2}{c}{$\begin{array}{c}\text { Average MII delay } \\
(\mathrm{min})\end{array}$} \\
\hline $10^{-4} \mathrm{M}$ & $5 \times 10^{-4} \mathrm{M}$ & - \\
- & - & 2 \\
- & - & 113 \\
- & 0.50 cycle & 134 \\
0.45 cycle & 0.60 cycle & 171 \\
0.45 cycle & 0.75 cycle & 66 \\
0.45 cycle & 0.50 cycle & -17 \\
\hline
\end{tabular}

"Replicate disks from one plasmodium were exposed to a subthreshold challenge of cadmium at 0.45 cycle and then reexposed to a suprathreshold challenge of cadmium at discrete intervals. Unexposed disks and disks exposed to only one of the two challenges were maintained as controls. All "samples were done in duplicate; the timing of mitosis between duplicate disks was $\mathbf{2 0}$ min or less. The experiment was evaluated by measuring the effect of single and multiple exposure upon the timing of the following mitosis, MII.

to determine if some subthreshold exposure to nickel early in the cell cycle would also protect against a suprathreshold dose of cadmium later in the cell cycle. Exposure to $6 \times 10^{-3} \mathrm{M} \mathrm{Ni}^{2+}$ at 0.45 cycle resulted in partial protection against a 5 $\times 10^{-4} \mathrm{M} \mathrm{Cd}^{2+}$ dose at 0.75 cycle (Table 6); nickel was reassigned to the protective group. Carrying this approach one step further, an exposure to $6 \times 10^{-3} \mathrm{M} \mathrm{Ni}^{2+}$ at 0.45 cycle protected against $10^{-2} \mathrm{M} \mathrm{Ni}^{2+}$ at 0.75 cycle (Expt 1, Table 7). Similarly,

TABLE 5

The Experimental Modei. with a Subthreshold Challenge of Cadmulu in the Early Position and Other Divalent Cations at Selected Concentrations in the Late Position"

\begin{tabular}{|c|c|c|c|c|c|}
\hline \multirow[b]{2}{*}{$\begin{array}{c}\text { Early dose at } \\
0.45 \text { cycle }\end{array}$} & \multirow[b]{2}{*}{$\begin{array}{l}\text { Late dose at } \\
0.75 \text { cycle }\end{array}$} & \multicolumn{3}{|c|}{$\begin{array}{l}\text { Average MII delay } \\
\text { (min) }\end{array}$} & \multirow[b]{2}{*}{ Type of response } \\
\hline & & $\begin{array}{l}\text { Early dose } \\
\text { alone }\end{array}$ & $\begin{array}{l}\text { Late dose } \\
\text { alone }\end{array}$ & $\begin{array}{l}\text { Multiple } \\
\text { challenge }\end{array}$ & \\
\hline $10^{-4} \mathrm{M} \mathrm{Cd}^{2+}$ & $8 \times 10^{-3} \mathrm{M} \mathrm{Co}^{2+}$ & 0 & 6 & 89 & Potentiation \\
\hline $\mathrm{I0}^{-1} \mathrm{MCd}^{2+}$ & $6 \times 10^{-3} \mathrm{M} \mathrm{Cu}^{2-}$ & 2 & 7 & 50 & Potentiation \\
\hline $10^{1} \mathrm{M} \mathrm{Cd}^{2 *}$ & $5 \times 10^{-3} \mathrm{M} \mathrm{Pb}^{2+}$ & 0 & 6 & 34 & Potentiation \\
\hline $10^{-4} \times \mathrm{Cd}^{++}$ & $10^{-2} \times \mathrm{Zn}^{2+}$ & 5 & 18 & 102 & Potentiation \\
\hline $10^{-+} \mathrm{MC} \mathrm{Cd}^{2+}$ & $5 \times 10^{-5} \mathrm{M} \mathrm{Hg}^{2+}$ & 3 & 263 & 203 & Protection \\
\hline $10^{-4} \times \mathrm{Cd}^{2-}$ & $10^{-2} M \mathrm{Ni}^{2+}$ & 2 & 169 & 127 & Protection \\
\hline $10^{-4} \mathrm{M} \mathrm{Cd}^{3+}$ & $5 \times 10^{-3} \mathrm{M} \mathrm{Fe}^{2+}$ & 2 & 2 & 17 & None detected \\
\hline $10^{-1} \times \mathrm{Cd}^{2+}$ & $5 \times 10^{-3} \mathrm{M} \mathrm{Mg}^{2+}$ & 4 & 4 & 19 & None detected \\
\hline
\end{tabular}

"Replicate disks were exposed to $10^{-4} \mathrm{M} \mathrm{Cd}^{2+}$ at 0.45 cycle and then to selected concentrations of other divalent cations at 0.75 cycle. The protocol was similar to those described in Tables 1 through 4. More than one plasmodium was necessary to cover the number of cations tested, and the data were summarized. 
TABLE 6

The Experimental Model wilh a Subihreshold Challenge of a Divalent Cation in the. Eari.y Position and a Suprathreshold Challfinge of Cadmium in the Late Position"

\begin{tabular}{ccccccc}
\hline & \multicolumn{5}{c}{$\begin{array}{c}\text { Average MIl delay } \\
\text { (min) }\end{array}$} \\
\cline { 3 - 5 } $\begin{array}{c}\text { Eariy dose at } \\
0.45 \mathrm{cycle}\end{array}$ & $\begin{array}{c}\text { Late dose at } \\
0.75 \mathrm{cycle}\end{array}$ & $\begin{array}{c}\text { Early dose } \\
\text { alone }\end{array}$ & $\begin{array}{c}\text { Late dose } \\
\text { alone }\end{array}$ & $\begin{array}{c}\text { Multiple } \\
\text { challenge }\end{array}$ & Type of response \\
\cline { 3 - 6 } $10^{-5} \mathrm{M} \mathrm{Co}^{2+}$ & $5 \times 10^{-4} \mathrm{M} \mathrm{Cd}^{2+}$ & 12 & 161 & $>210$ & Potentiation \\
$10^{-5} \mathrm{M} \mathrm{Cu}^{2+}$ & $5 \times 10^{-4} \mathrm{M} \mathrm{Cd}^{2+}$ & 0 & 161 & $>210$ & Potentiation \\
$10^{-5} \mathrm{M} \mathrm{Pb}^{2+}$ & $5 \times 10^{-4} \mathrm{M} \mathrm{Cd}^{2+}$ & 6 & 86 & 123 & Potentiation \\
$10^{-5} \mathrm{M} \mathrm{Zn}^{2+}$ & $5 \times 10^{-4} \mathrm{M} \mathrm{Cd}^{2+}$ & 9 & 70 & 143 & Potentiation \\
$10^{-5} \mathrm{M} \mathrm{Hg}^{2+}$ & $5 \times 10^{-1} \mathrm{M} \mathrm{Cd}^{2+}$ & 26 & 70 & 34 & Protection \\
$6 \times 10^{-3} \mathrm{M} \mathrm{Ni}^{2+}$ & $5 \times 10^{-4} \mathrm{M} \mathrm{Cd}^{2+}$ & 5 & 112 & 83 & Protection \\
$10^{-5} \mathrm{M} \mathrm{Fe}^{2+}$ & $5 \times 10^{-4} \mathrm{M} \mathrm{Cd}^{2+}$ & 0 & 103 & 82 & No response \\
$10^{-5} \mathrm{M} \mathrm{Mn}^{2+}$ & $5 \times 10^{-4} \mathrm{M} \mathrm{Cd}^{2+}$ & 7 & 103 & 86 & No response \\
$10^{-5} \mathrm{M} \mathrm{Ni}^{2+}$ & $5 \times 10^{-4} \mathrm{M} \mathrm{Cd}^{2+}$ & 0 & 161 & 159 & No response \\
\hline
\end{tabular}

"Replicate disks were exposed to selected concentrations of divalent cations at 0.45 cycle and then to $5 \times 10^{-4} \mathrm{M} \mathrm{Cd} d^{2+}$ at 0.75 cycle. The protocol was similar to those described in Tables 1 through 4 . More than one plasmodium was necessary to cover the number of cations tested, and the data were summarized.

$10^{-5} \mathrm{M} \mathrm{Hg}^{2+}$ at 0.45 cycle protected against $3 \times 10^{-5} \mathrm{M} \mathrm{Hg}^{2+}$ at 0.75 cycle (Expt 2 , Table 7). Finally, since Parizek (1957) has shown that $\mathrm{Zn}^{2+}$ protects against $\mathrm{Cd}^{2+}$ in the rat, a concurrent exposure at 0.75 cycle to $10^{-2} \mathrm{M} \mathrm{Zn}^{2+}$ and $5 \times 10^{-4} \mathrm{M} \mathrm{Cd}^{2+}$ was tested. Zinc did not protect against $\mathrm{Cd}^{2+}$ (Expt 3, Table 7) in Physarum.

\section{DISCUSSION}

Accommodation to cadmium has been previously reported in rats. Subcutaneous injection of 0.03 mmole of $\mathrm{Cd}^{2+} / 300 \mathrm{~g}$ animal produces microscopic testicular lesions in 2 to $4 \mathrm{hr}$ (Parizek and Zahor, 1956). Gunn et al. (1966a) found that animals are resistant to a second dose given 8 to 20 months later. In whole animals, protection against cadmium poisoning is thought to result from sequestering of cadmium by metallothionein, a low molecular weight $(\sim 10,000)$, SH-rich protein, as described by Margoshes and Vallee (1957). Experimentally, rats are protected by $\mathrm{Zn}^{2+}$ concentrations 80 to 200 times higher than $\mathrm{Cd}^{2+}$ when administered in three portions: $5 \mathrm{hr}$ prior to, simultaneously with, and $19 \mathrm{hr}$ after an initial dose of cadmium (Parizek, 1957). Protection against cadmium toxicity in the rat is also provided by thiol compounds (Gunn et al., 1966b), estrogens (Gunn et al., 1965), cobalt (Gunn et al., 1968), and selenium (Kar et al., 1960: Mason and Young, 1967; Gunn and Gould, 1967). Whether or not protection against cadmium toxicity at the single cell level, as in Physarum, and at multicellular levels, as in the rat, reflects the same phenomenon remains to be seen.

The protective response in Physarum differs from that of the rat in at least three characteristics: (1) Earlier exposure to $\mathrm{Co}^{2+}$ or $\mathrm{Zn}^{2+}$ antagonizes the reaction to later exposure to $\mathrm{Cd}^{2+}$ (Table 6); (2) concurrent exposure to $\mathrm{Zn}^{2+}$ does not protect against $\mathrm{Cd}^{2+}$ (Expt 3. Table 7); and (3) cell extracts prepared when the protective 


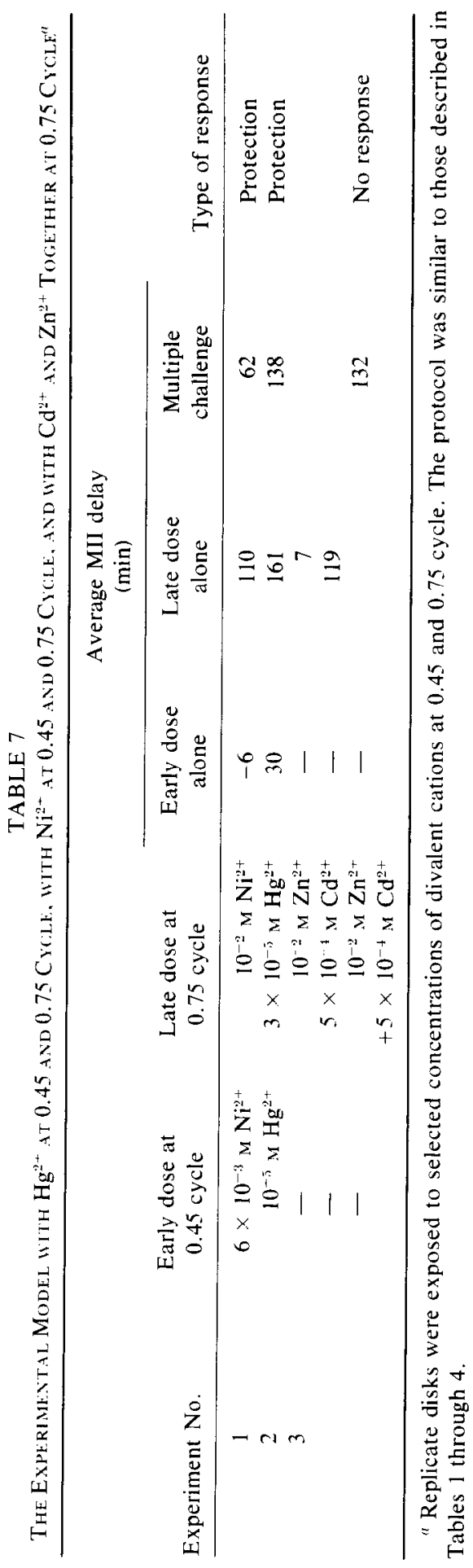


response is fully developed do not contain a low molecular weight, ${ }^{109} \mathrm{Cd}$-binding protein (metallothionein) when analyzed by gel filtration (Lesowitz and Mitra, unpublished data).

As an experimental system for the study of biological accommodation, Physarum offers advantages of simplicity, speed, and sensitivity. Targets for cadmium toxicity can be identified at the cellular level, and studies can be conducted in hours, within the time span of the cell cycle. The sensitivity of the system is greater than we had thought, since full protection was elicited by a challenge one order of magnitude lower $\left(10^{-5}\right)$ than the subthreshold challenge previously used (Chin et al., 1978).

The protective response is not restricted to challenges at 0.45 and 0.75 cycle, as might be expected from changes in metabolic activities which occur as the cell progresses through the cell cycle (Mitchison, 1971) but is available during the first three quarters, if not all, of the cycle (Table 3). Protection falls off when the two challenges encroach upon each other, implying that some interval of time $(\sim 30$ $\min$ ) is necessary for the protective response to develop fully (Table 4). Rescue is worthy of special note: When the cell is exposed to $10^{-4} \mathrm{M} \mathrm{Cd}^{2+}$ at $0.06,0.16$, and 0.27 cycle, the respective mitotic delays are 122,130 , and $0 \mathrm{~min}$. Replicate disks from the same plasmodia exposed to $5 \times 10^{-4} \mathrm{M} \mathrm{Cd}^{2+}$ at 0.82 cycle are delayed by $158 \mathrm{~min}$. When these early challenges and the late exposure are combined in single replicate disks, the respective mitotic delays are 11,80 , and $16 \mathrm{~min}$. Multiple challenges in these configurations result in protection, total or in part, of the mitotic delays brought on by each challenge singly (Expt 1 , Table 3 ). It is as if the early challenge induced a mitotic delay of its own and stimulated the protective response against the later challenge and that the later challenge somehow rescued the cell from the mitotic delay initiated by the early challenge. We do not profess to understand these curious observations at this time. The sensitivity to cadmium at 0.06 and 0.16 cycle are coincident with the $S$ period (Chin et al., 1978; Nygaard et al., 1960), and the resulting mitotic delay may reflect some interference with DNA synthesis (Sachsenmaier and Rusch, 1964). Springgate et al. (1973) have demonstrated that DNA polymerase $I$ is a zinc-containing enzyme and that replacement of $\mathrm{Zn}^{2+}$ by $\mathrm{Cd}^{2+}$ results in loss of enzyme activity. These observations have prompted an inquiry on our part into the effect of cadmium on DNA synthesis and other cellular events associated with the $S$ period of the cell cycle as well as a continuation of studies on the effect of cadmium upon the rest of the cycle.

Our model of accommodation was conceived to study the effect of low-level (subthreshold) exposures upon the integrity of the cell. We have achieved some initial success toward our long-range goal, which is to determine how a cell responds to a multiplicity of low-level stressors. In Physarum, a subthreshold exposure to cadmium elicits a protective response against a suprathreshold exposure to cadmium. This situation is complicated when types of exposures are mixed; all three possible responses of our model (Chin et al., 1978) are realized: protection, potentiation, and no response. The validity of the model is reaffirmed. The combinations of metals tested in this report reflect a simple initial approach and are far from exhaustive in concentrations that could be tested. Even so, the results of mixed exposures early and late in the cell cycle suggest that the constancy of groupings is more than coincidental (Tables 5 and 6 ). 
This study has shown, as Dinman suggested in 1972, that the concept of the threshold, at least in Physarum, is not a simple one. Seemingly innocuous subthreshold challenges affect the integrity of the organism, the manner in which Physarum handles a stressor being dependent upon its prior history of exposures as well as upon the nature of the immediate agent and its concentration.

Whether protection and potentiation by subthreshold challenge are available in more developed mammalian (including human) cells is of immediate interest to us. If so, in regard to setting standards for environmental pollutants, protection or potentiation will point to the need for consideration of stressors to which an organism is likely to have been or will be exposed. Since the prospect of studying all combinations of stressors in the biosphere looms as a formidable task, a more reasonable approach would be to identify - and to exploit-these cellular processes involved in accommodation.

\section{ACKNOWLEDGMENTS}

We thank Paul D. Friedrich for both his conceptual and technical contributions to this study. This project was supported by USPHS Grant GM 00803 from the NIEHS.

\section{REFERENCES}

Bulmer, F. M. R., Rothwell, H. E., and Frankish, E. R. (1938). Industrial cadmium poisoning. A report of fifteen cases, including two deaths. Canad. J. Public Health 29, 19-26.

Chin, B.. Friedrich, P. D., and Bernstein. I. A. (1972). Stimulation of mitosis following fusion of plasmodia in the myxomycete Physarum polycephalum. J. Gen. Microbiol. 71, 93-101.

Chin, B. Lesowitz, G. S., Bernstein. I. A., and Dinman, B. D. (1978). A Cellular model for studying accommodation to environmental stressors: A protective response to subtoxic exposure to cadmium. Environ. Res. 16, 423-431.

Dinman, B. D. (1972). "Non-concept" of "no threshold" chemicals in the environment. Science 175, $495-497$.

Emmerson. B. T. (1970). "Ouch-ouch" disease: The osteomalacia of cadmium nephropathy. Ann. Internal Med. 73, 854-855.

Ferm, V. H. (1972). Developmental malformations induced by cadmium. A study of timed injections during embryogenesis. Biol. Neonat. 19, 101-107.

Ferm. V. H., and Carpenter, S. J. (1967). Teratogenic effect of cadmium and its inhibition by zinc. Nuture (London) 216, 1123.

Flick. D. F.. Kraybill. H. F., and Dimitroff, J. M. (1971). Toxic effects of cadmium: A review. Environ. Res. 4, 71-85.

Gunn, S. A., and Gould. T. C. (1966). Specificity of response in relation to cadmium, zinc and selenium. In "Selenium in Biomedicine" (O. H. Muth, J. E. Oldfield. and Ph. H. Weswig, Eds.) pp. 395-413. Avi. Westport, Conn.

Gunn, S. A., Gould, T. C. and Anderson, W. A. D. (1963). Cadmium-induced interstitial cell tumors in rats and mice and their protection by zinc. J. Nat. Cancer Inst. 31, 745-759.

Gunn. S. A., Gould, T. C.. and Anderson. W. A. D. (1965). Protective effect of estrogen against vascular damage to the testis caused by cadmium. Proc. Soc. Expt. Biol. Med. 119, 901-905.

Gunn. S. A., Gould, T. C., and Anderson. W. A. D. (1966a). Loss of selective injurious vascular response to cadmium in regenerated blood vessels of testis. Amer. J. Pathol. 48, 959-969.

Gunn, S. A., Gould, T. C., and Anderson, W. A. D. (1966b). Protective effect of thiol compounds against cadmium-induced vascular damage to testis. Proc. Soc. Expt. Biol. Med. 122, 1036-1039.

Gunn, S. A., Gould, T. C., and Anderson, W. A. D. (1968). Specificity in protection against lethality and testicular toxicity from cadmium. Proc. Soc. Expt. Biol. Med. 128, 591-595.

Haddow, A., Roe, F. J. C. Dukes, C. E., and Mitchley, B. C. V. (1964). Cadmium neoplasia: Sarcomata at the site of injection of cadmium sulphate in rats and mice. Brit. I. Cancer 18 , $667-673$.

Kar, A. B., Das, R. P.. and Mukjeri. B. (1960). Prevention of cadmium induced changes in the gonads 
of rat by zinc and selenium-A study in antagonism between metals in the biological system. Proc. Nat. Inst. Sci. India 26, (Suppl. part B), 40-50.

Lucis, O. J., Lueis, R., and Aterman, K. (1972). Tumorigenesis by cadmium. Oncology 26, 53-67.

Lucis, O. J.. and Zahor, Z. (1956). Effect of cadmium salts on testicular tissue. Nature (London) 177. $1036-1037$.

Malcolm. D. (1972). Potential carcinogenic effect of cadmium in animals and man. Ann. Occup. Hyg. $15,33-36$.

Margoshes. M., and Vallee, B. L. (1957). A cadmium protein from equine kidney cortex. J. Amer. Chem. Soc. 79, 4813-4814.

Mason, K. E.. and Young, J. O. (1966). Effectiveness of selenium and zinc in protecting against cadmium-induced injury of the rat testis. In "Selenium in Biomedicine" $1 \mathrm{O}$. H. Muth. J. E. Oldfield, and Ph. H. Weswig, Eds.). pp. 383-394. Avi Westport, Conn.

Mitchison, J. M. (1971). "The Biology of the Cell Cycle." Cambridge Univ. Press, London.

Nygaard, O. F. Guttes, S., and Rusch. H. P. (1960). Nucleic acid metabolism in a slime mold with sychronous mitosis. Biochim. Biophys. Acta 38, 298-306.

Page, A. L., and Bingham, F. T. (1973). Cadmium residues in the environment. In "Residue Reviews" (F. A. Gunther, Ed.), Vol. 48, pp. 1-44. Springer-Verlag, New York.

Parizek, J. (1957). The destructive effect of cadmium ion on testicular tissue and its prevention by zinc. J. Endocrinol. 15, 56-63.

Parizek, J., and Zahor, Z. (1956). Effect of cadmium salts on testicular tissue. Nature (London) 177, $1036-1037$.

Sachsenmaier, W., and Rusch, H. P. (1964). The effect of 5-fluoro-2'-deoxyuridine on synchronous mitosis in Physarum polycephalum. Exp. Cell Res. 36, 124-133.

Scharpf, L. G., Hill, I. D., Wright, P. L., Plank, J. B., Keplinger, M. L., and Calandra, J. C. (1972). Effect of sodium nitrilotriacetate on toxicity, teratogenicity, and tissue distribution of cadmium. Nature (London) 239, 231-234.

Schroeder, H. A. (1965). Cadmium as a factor in hypertension. J. Chron. Dis. 18, 647-656.

Springgate. C. F., Mildvan, A. S., Aramson, R., Engle, J. L., and Loeb, L. A. (1973). Escherichia coli deoxyribonucleic acid polymerase I, a zinc metalloenzyme. J. Biol. Chem. 248, 5987-5993.

Vallee. B. L.. and Ulmer. D. D. (1972). Biochemical Effects of mercury, cadmium and lead. Annit. Rev. Biochem. 41, 91-127. 